\title{
EFFECT OF FIELD INFESTATION WITH WHITE GRUB ON PHYSICAL AND CHEMICAL PROPERTIES OF SUGARCANE
}

\author{
SANAA A. M. IBRAHIM
}

Plant Protection Research Institute, ARC, Dokki, GIza

(Manuscript received 28 February 2010)

\begin{abstract}
This study was conducted during two successful growing seasons 2008 and 2009 at different sugarcane plantations in Qina and Sohag governorate, to clarify the physical and chemical changes of sugarcane plants under natural field infestation with white grub. White grub infestation reduces weight and stalk height of plant while the number of internodes/ stalk was increased. Chemical analysis of sugarcane juice showed that, the infestation reduced the brix (weight and volume), purity, sucrose/can, fiber, pol, and sugar recovery by $5.85,6.30,7.65,8.35$, $19.35,9.64$ and $12.57 \%$, respectively compared to the uninfested plants. The effect of infestation on protein and isozyme banding pattern was also detected. Several protein bands were disappeared with the infestations and changed in peroxidase and estrase banding profiles was found.
\end{abstract}

Key words: Sugarcane, physical and chemical properties of sugarcane, Protein, Isozyme banding pattern

\section{INTRODUCTION}

Sugarcane (Saccharum officinarum) is globally the main source of sugar, followed by sugar beet (Zucchi et al, 2002). It is grown in tropical and sub-tropical regions of the world in a range of climates from hot dry environment near sea level to cool and moist environment at higher elevations. Uses of sugarcane include the production of sugar, molasses, rum, soda and ethanol for fuel. Egyptians are considered to be the pioneers in refined sugar industry since the ninth and tenth centuries. The total sugarcane cultivated area reached about 312 thousand feddans, (about $80 \%$ ) concentrated in middle and Upper Egypt (Shalaby et al, 2007).

Sugarcane crop is subjected to attack by a large number of insect pests, one of these insects is the root-feeding larvae of white grub, (Heteronychus licas) (Coleoptera: Scarabaeidae) (Koppenhofer and Eugene 2008). It destroys the plant roots and as the crop approach maturity, the larvae eat the lower stems, and might burrow into them (Koppenhofer and Eugene 2008).

The white grub species have an annual life cycle with adults emerging summer to lay eggs in the soil among the roots of the host plants (Potter, 1998), most larvae have developed into the third instar continue feeding until pupation. The 
extensive feeding activity destroyed large areas of sugarcane especially under warm dry conditions. Infested plants showed symptoms similar those seen during drought. Sadoyama et al., (2001) reported that dead leaves and wilted stalks were prevalent, immediately before the harvesting and the damaged stools were easily pulled from the ground, i.e. apparently the roots were damaged. The dead plants were piled in heaps at the edges of fields and not harvested (Sadoyama et al., 2001).

The present investigation was carried out in Sohage and Qiena districts during the growing seasons of 2008 and 2009 in order to study the effect of white grub infestation on certain quantitative and qualitative characteristics of sugarcane crop. Also the changes in protein and isozyme banding pattern under the infestation were investigated.

\section{MATERIALS AND METHODS}

\section{I-Physical and Chemical analysis of sugarcane plants}

This study was carried out for uninfested plants and another infested with white grub at Sohage and Qina districts during the growing seasons of 2008 and 2009. At harvest, an assessment of certain physical properties of C.9/54 sugarcane variety was performed. Two samples, each 50 infested stalks were taken as one from each districts. Mean Stalk weight $(\mathrm{g}$.$) , diameter (\mathrm{cm})$ and height $(\mathrm{m})$, length of internode $(\mathrm{cm})$ and mean number of internodes per stalk was recorded.

Chemical analyses of the juice produced from the previous plants were done. One liter fresh juice from each of control and infested plants were taken for calculating the characters according to the formula described by Sugar and Integrated Industries Company (S.I.I.C.) (Mathur, 1981) to determine the following parameters:

- Brix value (the percent of total soluble solids in $100 \mathrm{~cm}^{3}$ of juice).Sucrose percent. Purity percent $=($ Sucrose $\% /$ brix $\%) \times 100$.

- Pol. $=($ Sucrose \%) $\times$ Pol factor.

- Sugar recovery percent $=$ Richness $\% \times$ Purity $\%$.

- Richness $=$ (Sucrose in $100 \mathrm{mg} \times$ factor $) / 100$.

- Factor $=100$ - (fiber $\%+$ physical impurities $\%+$ percent water free from sugar). The Fiber \%, pol factor and reducing sugar were also determined according to the method described in Mathur, (1981).

\section{II-Protein and isozyme banding patterns}

\section{SDS-PAGE}

Proteins were extracted from fresh young tissue of sugarcane leaves of white grub infested plants as well as uninfested plants. SDS-Poly Acrylamide Gel 
Electrophoresis (SDS-PAGE) was performed for the total storage proteins according to Laemmli , (1970).

2. Isozyme analysis: Isozymes were extracted from infected and uninfected plants. Analysis was performed using PAGE according to the method of Stegemann et al., (1983).

\section{a. Peroxidase (PX)}

Was detected by incubating the gel in darkness for one hour at $370 \mathrm{C}$ in a mixture of: $85 \mathrm{ml}(100 \mathrm{mM})$ potassium acetate $(\mathrm{pH} \mathrm{4.76)}, 15 \mathrm{ml}$ of $10 \%$ benzidine (in 95\% ethanol), and $1 \mathrm{ml} \mathrm{H}_{2} \mathrm{O}$.

\section{b. Esterase (EST)}

was detected by incubating the gel in darkness for one hour at $370 \mathrm{C}$ in a mixture of : $100 \mathrm{ml}$ phosphate (0.15 M pH 7.2), $20 \mathrm{mg}$ 1-naphthylacetate dissolved in $2 \mathrm{ml}$ acetone and $50 \mathrm{mg}$ fast blue RR salt.

\section{Fixation}

The gels were fixed in $50 \%$ glycerol for one hour and then soaked in distilled water for several hours prior to scoring and photographed. RF value of each band was calculated as:-

$\mathrm{RF}=\quad$ Distance traveled by the band from the top of the running gel.

Distance traveled by the tracking dye

\section{RESULTS AND DISCUSSION}

In the present study, mean weight of stalk decreased (45.87\%) in the infested plants compared to the uninfested plants (control).A similar tendency was also observed for the stalk height, the normal plant $2.10 \mathrm{~m}$ while the infested plant was $1.70 \mathrm{~m}$ only (Table 1 ). On the other side, mean number of internodes/ stalk increased (43.44\%) with the infestation, while the internode's length and diameter were remarkably decreased (47.13 and 31.43\%), respectively (Fig.1 and Table,1). The data presented in Table (2) indicate that the white grub infestation reduces the brix ,purity, sucrose/cane , fiber ,pol ,and sugar recovery by,6.3,7.65,8.35,19.35,9.64, and $12.57 \%$, respectively when compared with those of the control. These results agreed with the reported by Abdul-Khaliq et al., 2005. Also Goel et al. (1983) indicated that, the heavily infestation on cane by $M$. glomerata reduce the cane weight, juice brix, sucrose content of the juice and purity by $51.61,27.69,39.0$ and $13.39 \%$, respectively. Anonymous (1987) mentioned to yield losses caused to sugarcane by $P$. iceryi and damage level of the 2 components of loss, cane weight and sucrose 
content. Atiqui and Murad (1992) assessed the loss of sucrose due to infestation by Saccharicoccus sacchari.The results indicated that decreased the sucrose and sugar content of the cane and its purity (with average losses in sugar brix, pol, purity and available sugar content of $10.64,16.44,6.14$ and $12.92 \%$, respectively).

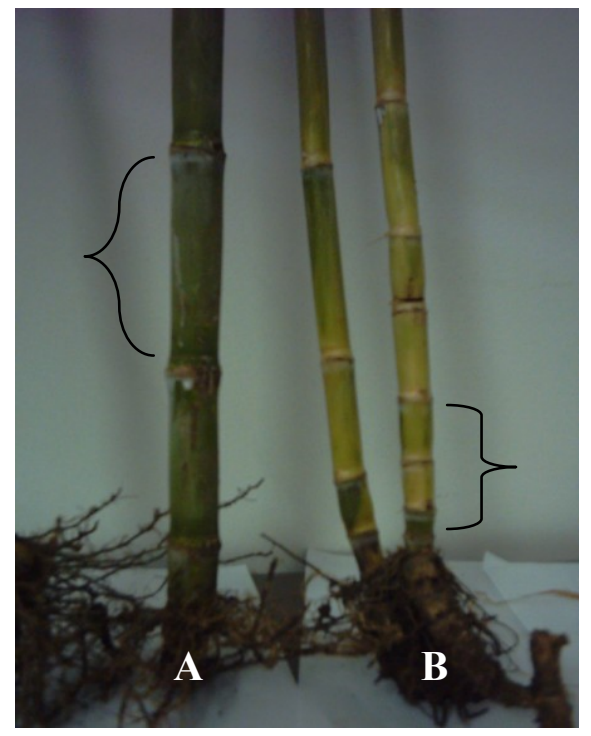

Fig.1 : Effect of white grub infestation on internodes size and length.
A: un-infested plant
B: infested plant 
Table 1. Effect of infestation with White Grub (Heteronychus licas) on physical properties of Sugarcane

\begin{tabular}{|l|c|c|c|c|c|c|c|c|}
\hline \multirow{2}{*}{$\begin{array}{c}\text { Plant } \\
\text { samples }\end{array}$} & \multicolumn{2}{|c|}{ Stalk weight (Gm.) } & \multicolumn{2}{c|}{ Stalk height (m.) } & \multicolumn{2}{c|}{ Internodes length(Cm.) } & \multicolumn{2}{c|}{ Stalk diameter (Cm) } \\
\cline { 2 - 10 } & Mean & Loss\% & Mean & Loss\% & Mean & Loss\% & Mean & Loss\% \\
\hline uninfested & 1.09 & 0.0 & 2.10 & 0.0 & 17.4 & 0.0 & 7 & 0.0 \\
\hline infested & 0.59 & 45.87 & 1.70 & 14.05 & 9.2 & 47.13 & 4.8 & 31.43 \\
\hline
\end{tabular}

Data are means of 50 samples from infested and 50 samples of control plants

Table 2. Effect of infestation with White Grub (Heteronychus licas) on certain chemical properties of Sugarcane juice.

\begin{tabular}{|c|c|c|c|c|c|c|c|c|c|c|c|c|c|c|}
\hline \multirow[t]{2}{*}{$\begin{array}{l}\text { Plant } \\
\text { samples }\end{array}$} & \multicolumn{2}{|c|}{$\begin{array}{c}\text { Mean of Brix of } \\
\text { weight }\end{array}$} & \multicolumn{2}{|c|}{$\begin{array}{l}\text { Mean of Brix of } \\
\text { volume }\end{array}$} & \multicolumn{2}{|c|}{ Purity\% } & \multicolumn{2}{|c|}{ Sucrose/ Gm } & \multicolumn{2}{|c|}{ Fiber\% } & \multicolumn{2}{|l|}{ Pole } & \multicolumn{2}{|c|}{$\begin{array}{l}\text { Sugar } \\
\text { recovery\% }\end{array}$} \\
\hline & Mean & Loss $\%$ & Mean & Loss $\%$ & Mean & Loss $\%$ & Mean & Loss $\%$ & Mean & Loss $\%$ & Mean & Loss $\%$ & Mean & Loss $\%$ \\
\hline uninfested & 19.65 & 0.0 & 21.26 & 0.0 & 86.3 & 0.0 & 16.17 & 0.0 & 12.4 & 0.0 & 13.8 & 0.0 & 11.14 & 0.0 \\
\hline infested & 18.5 & 5.85 & 19.92 & 6.30 & 79.7 & 7.65 & 14.82 & 8.35 & 10 & 19.35 & 12.47 & 9.64 & 9.74 & 12.57 \\
\hline
\end{tabular}

Data are means of 50 samples from infested and 50 samples of control plants 
Protein samples isolated from leaves blonged to the infested or the uninfested were resolved using SDS-PAGE (Figure 2). The data revealed that the white grub infestation reduced the protein content, several protein bands were disappeared compared to the uninfested plants. The band with molecular weight of $200 \mathrm{kDa}$ was found in infested and their uninfested plants. The band with molecular weight of 116 kDa was observed only in theuninfested and absent in the infested plants.

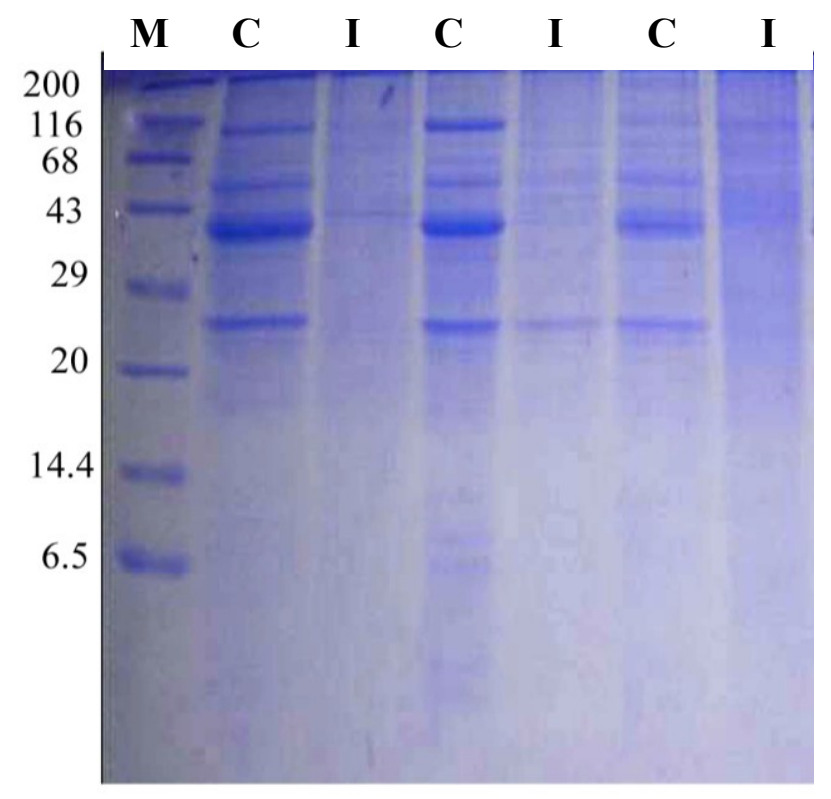

Fig.2.Protein banding patterns in the leaves of sugarcane with and without white grub infestation. M, wide rang protein marker, C, uninfestsd and I, infested plant . Protein was extracted from three samples from each infested and uninfested plant.

Effect of larval feeding on sugarcane was detected by comparing the peroxidase isozyme banding patterns in the leaves. Data presented in Figure 3-A and Table, 3, show the peroxidase profiles and RF values of the uninfested and infested plants. A total of five bands were characterized. The electerophoretic bands show variation in their intensities among the different profiles under infestation. For instance, the band with RF 0.08 can be considered a common band in infected plants and their uninfested.

The band with RF 0.44 found only in the infested canes. These results are in agreement with those reported by Ranju and Shahi (2002), there was a significant 
variation in peroxidase isozyme patterns in number, position and intensity of bands in four sugarcane cultivars (BO91, BO110, BO120, and BO128) under field infestation. Similar results were obtained by Sangeeta and Gupta (2004).

A

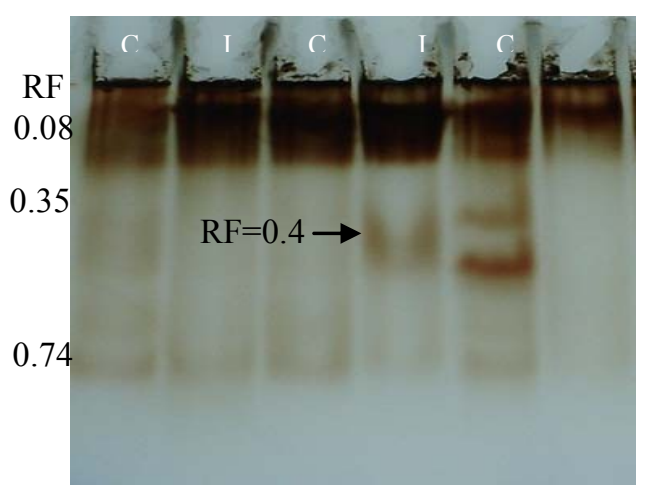

$\mathbf{B}$

$\mathrm{RF}$ 0.06

0.30

0.4

Fig. 3.The effect of white grub infestation on sugarcane isozyme banding pattern A: peroxidase isozyme profiles, B: Esterase banding patterns (C. uninfested and I. infested plants).

Table 3. The RF value of peroxidase and Estrase isozyme of the uninfested and infested sugarcane plants.

\begin{tabular}{|c|c|c|c|c|c|c|c|c|c|c|c|c|c|}
\hline & \multicolumn{7}{|c|}{ Peroxidase } & \multicolumn{5}{c|}{ Estrase } \\
\hline $\mathrm{RF}$ & $\mathrm{C}$ & $\mathrm{I}$ & $\mathrm{C}$ & $\mathrm{I}$ & $\mathrm{C}$ & $\mathrm{I}$ & $\mathrm{RF}$ & $\mathrm{C}$ & $\mathrm{I}$ & $\mathrm{C}$ & $\mathrm{I}$ & $\mathrm{C}$ & $\mathrm{I}$ \\
\hline 0.08 & + & + & + & + & + & + & 0.068 & - & + & + & - & - & - \\
\hline 0.35 & + & - & - & - & + & - & 0.227 & - & + & - & - & - & - \\
\hline 0.44 & - & - & - & + & - & - & 0.300 & - & - & + & + & - & - \\
\hline 0.49 & + & - & - & - & + & - & 0.454 & - & - & + & - & - & - \\
\hline 0.74 & + & + & + & + & + & - & 0.625 & + & + & + & + & + & + \\
\hline
\end{tabular}

Banding patterns of esterase extracted from the young leaves of sugarcane plants are presented in Fig.3-B and Table, 3. The band with RF 0.068 was present with low intensity in the infested plants and absent in its uninfested. Whereas that band with RF 0.454 was found only in the uninfested. The band with RF 0.625 is considered as common band for all tested sugarcane plants these results agreed with those reported by Sangeeta et al., (2005).

Tacking all together the data of the present study indicate that white grub infestation affects sugarcane plant physical and chemical properties, reduce the juice quality which affect the sugar industry in Egypt, indicating the need of establishing an effective IPM program to control white grub infestation in sugarcane plantation. 


\section{REFERENCES}

1. Abdul Khaliq, M., A. W. Akram, J. K. Choi and, J. J. Lee. 2005. Effect of Plant Factors, Sugar Contents, and Control Methods on the Top Borer (Scirpophaga nivella F.) Infestation in Selected Varieties of Sugarcane. Entomological Research, 35(3):153-160

2. Anonymous. 1987. A report from Mauritius Sugar Institute.

3. Atiqui, M.U.A. and H. Murad. 1992. Assessment of loss in sucrose content of sugarcane due to sugarcane mealy bug, Saccharicoccus sacchari (Ckll). J. of Insect. Sci., 5(2): $196-197$.

4. Goel,S. C., T. A. V. S. Raghunath and S. C. Goel. 1983. Losses due to scale insect in sugarcane variety $\mathrm{CO}$. A 7602. Insect Ecology and resource management. 2:142-146.

5. Koppenhofer, A. M. and M. F. Eugene. 2008. Attraction of four entomopathogenic nematodes to four white grub species. Journal of Invertebrate Pathology, 99(2):227-234.

6. Laemmli, U. K. 1970. Cleavage of structural protein during the assembly of the head of bacteriophage $T_{4}$. Nature, 227:680-685.

7. Mathur, R. B. L. 1981. Handbook of cane sugar technology. Second revised and enlarged edition. Oxford and IBH publishing Co. Pvt. Ltd., New Delhi and Calcuta.33-48.

8. Potter, D. A. 1998. Destructive Turfgrass Insects :Biology, Diagnosis and Control. Ann. Arbor Press, Chelsea.392.

9. Ranju, K. and V. K. Shahi. 2002. Use of peroxidase isozyme in testing the genetic purity of some micropropagated plant of sugarcane. Sugar Tech., 4(3): 173-175.

10. Sadoyama, Y., H. Oroku and H. Nakamori. 2001. Injury of sugar cane roots by the white grub, Dasylepida sp.(Coleoptera: Scarabaeidae), in the Miyako Islands., Jpn. J. Appl. Entomol. Zool. 2: 89-91

11. Sangeeta, S. and P.S. Gupta. 2004. Diversity of peroxidase isozyme for identification and characterization of Saccharum species clones. Indian Journal of Genetics and Plant Breeding, 64(4): 271-274

12. Sangeeta, S., P. S. Gupta and B. L. Srivastava. 2005. Genetic relationship and clustering of some sugarcane genotypes based on esterase, peroxidase and amylase isozyme polymorphism, Cytologia.,70(4): 355-363. 
13. Shalaby, M. S. I., A. M. El-Rawy, H. A. Saleh and M. I. El-Khouly. 2007. Role of sugarcane varieties and potassium fertilizer in the management of lesser sugarcane bored, Chilo Agamemnon blezynski and Red striped soft scale. Egypt J. Agric. Res.,85(6): 2139-2149.

14. Stegmann, H. W., H. Burgermeister and F. Krogerrecklen. 1983. Manual gel electrophoresis and isoelecteric focusing with the apparatus PANTA-PHOR INST. Biochem. Messewg 11, D-3300 Braunschweig West-Germany.

15. Zucchi, M. I., H. Arizono, V.A. Morais, M. H. P. Fungaro and M. L. C. Vieira. 2002. Genetic instability of sugarcane plants derived from meristem cultures. Genetics and Molecular Biology, 25(1): 91-95. 


\section{تأثير الاصـابة الحقلية بحثـرات الجعال على الخصائص الطبيعيـة \\ والكيماوية لنباتات قصب السكر}

سـناء عبد القادر محمـــ (براهيم

$$
\text { معهد بحوث وقاية النباتات - مركز البحـوث الزراعيـة }
$$

تمت هذه الدراسة خلال موسمى ^ . . rو 9 . . ب فى مناطق مختلفة لزراعات قصب السكر فى

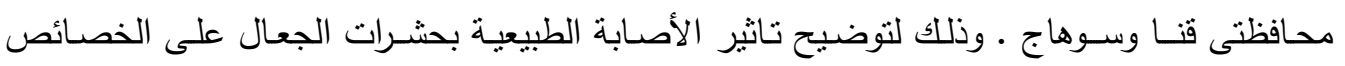
الطبيعية والكيماوية لنبات قصب السكر • وقد أوضحت النتائج أن الاصـابة بالجعال ادت الى تقليل كلاً

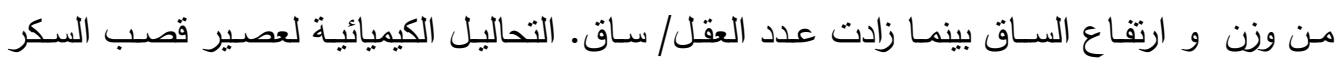

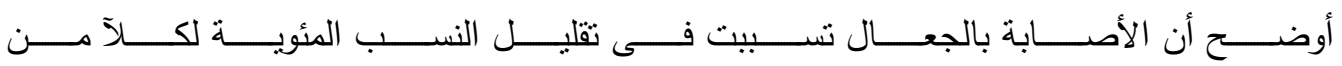

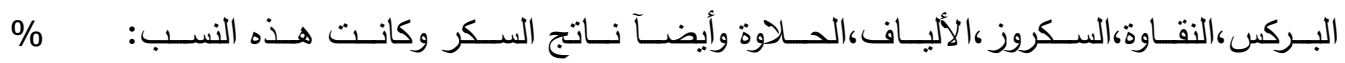
6.30,7.65,8.35,19.35,9.64 على الترتيب مقارنـة بالنباتات الغير مصابة (الكنترول). كما تم دراسة

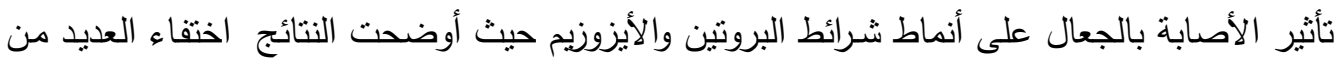

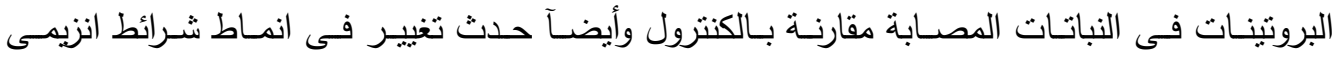

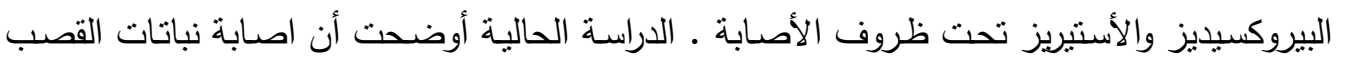

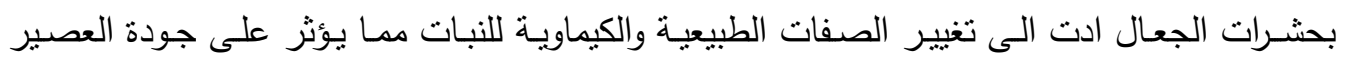

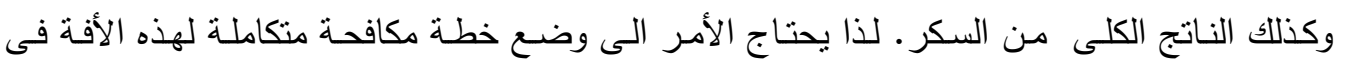

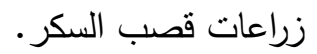

